the Royal Society, the award of the Murchison Medal of the Geological Society of London and the Penrose Medal of the Geological Society of America.

Like all of his generation, Coleman's geological interest was wide, and we have from his pen papers dealing with such contrasted subjects as ore deposits and palæontology, pre-Cambrian stratigraphy and Pleistocene geology. Wide as was the scope of his work, however, it is probable that he will be remembered most for two outstanding studies, the geology of the great nickel ore-field of Sudbury, Ontario, and the evidence and history of past ice ages. The mapping of the Sudbury district involved much more than a study of the ores themselves, for it necessitated the unravelling of the geological history of a most complicated series of pre-Cambrian strata which in its turn had far-reaching effects on the interpretation of the structure of the "Canadian Shield" as a whole. Notwithstanding the great amount of work that has been done in this area by the geologists of the Dominion Geological Survey, the Ontario Department of Mines and the International Nickel Co., there has been substantially no change made in the rock groups that Coleman differentiated in his map and report of 1913.

In assessing the merit of this study one has also to remember the conditions under which it was executed. When Coleman entered the field it was still the typical wildermess of northern Canada, without roads of any kind and, in much of the area, without even trails. Owing to the somewhat unusual topography also, canoeing did not provide that ready means of access which is common in Ontario and Quebec, so that Coleman had to carry his survey through mostly on foot. Notwithstanding these difficulties his map has survived the exacting demands made on it by mining engineer and prospector, and the only change of any moment has been the recognition of faulting in the south-western corner. Some more significant alterations have been made, however, in his interpretation of the origin of the ores themselves, and there are few geologists now working in the district who would accept his theory of the formation of the sulphides by liquation from the adjacent norite either through the action of gravity or by some form of filter-pressing.

In his other important study, that of the past ice ages, Coleman was the first to present conclusive evidence of the glacial origin of the Cobalt conglomerate and to show its similarities with Pleistocene glaciation. He was convinced that the tillite could be traced as a definite horizon throughout the Huronian rocks of Ontario, but some doubt has been cast on this thesis by Collins's identification of the Ramsay Lake conglomerate as an ancient regolith.

No reference to Coleman's work would be complete without a mention of his love for travel and exploration. He made a point of seeing for himself the most significant features of world geology and to this end travelled much in Europe, Africa, India, Australia and North and South America. It is this immediate familiarity with the field observations that is reflected in his most interesting book on "Ice Ages, Recent and Ancient" published in 1926, and one can well guess that it was from the same source that he derived that enthusiasm that made him so highly esteemed and successful a professor in Toronto. He also had the happy gift of portraying the scenes he had visited with water-colour sketches, one of special interest being probably the earliest picture we have of Mystery Mountain (Mt. Waddington) in the Coast Range of British Columbia. He did not restrict his painting to scenery alone but also applied it, in dramatic fashion, to the illustration of his theories of ore genesis.

T. C. Phemister.

\section{Dr. Louis Fabry}

WE regret to announce the death of Louis Fabry, the well-known French astronomer. He was born in 1862 and belonged to a family that has given eminent men of science to their country, one brother, Prof. Charles Fabry, being the renowned physicist; another brother, Prof. Eugene Fabry, is a mathematician of repute.

At the early age of sixteen years, Louis Fabry received the degree of Bachelier ès sciences, and after various other academic distinctions he was appointed to the Observatory of Paris in 1884 as a student astronomer. Two years later he went as assistant astronomer to the Observatory of Nice, and in 1890 he took up work at Marseilles Observatory, from which he retired fourteen years ago.

Fabry's interests in astronomy were very wide and he wrote on a diversity of astronomical matters. In 1893 he was awarded the degree of Docteur es sciences mathematiques for his thesis presented before the Faculty of Sciences in Paris, in which he showed that the absence of strongly hyperbolic orbits among the comets proved that these bodies were members of the solar system. In 1899 he dealt with the influence of his theory of cometary orbits on the hypotheses of cosmogony, and showed that the attraction of the distant stars and the lack of homogeneity in the primitive nebula, although not very considerable, were, nevertheless, not without influence, and their simultaneous intervention was sufficient to explain both the rotation of the sun and also the direct motion of the planets. In addition, these factors were responsible for causing the comets to deviate from the line which would make them fall towards the centre of the nebula, that is, the sun, and so prevented them from possessing perihelion distances that would otherwise have been practically zero.

Fabry did much useful work on minor planets, in particular, in the compilation of tables for facilitating the computation of ephemerides. The improvement of orbits by means of four observations is a wellknown method but it involves rather complicated algebraic calculations. Fabry partly overcame this difficulty by means of new differential formulæ which introduced considerable simplifications in the solution of the problem. The method was later applied with great success by other computers. His tables on the perturbations of minor planets with small eccentricity and also small inclination proved very effective for the computation of the orbits and 
ephemerides of these bodies. Amongst his other lines of research may be mentioned his work on refraction, his tables for the determination of the geographical visibility, measurement of altitudes by the barometer, studies in eertain problems of seismology, and also his zenithal apparatus, described in the Bulletin astronomique, 12, 148, which was capable of making observations simultaneously of the zenith and stars in the vicinity. He was four times awarded prizes by the Paris Academy of Sciences. Astronomical science has lost one whose versatility contributed so much to its progress.

M. D.

\section{Prof. N. V. Nassonov}

Prof. Nicolar Victorovich Nassonov, who has recently died in Leningrad, was the oldest member of the Russian (now U.S.S.R.) Academy of Sciences. He was born at Moscow on February 27, 1855, and in 1874 entered the University of Moscow where he studied under the well-known zoologist, Prof. A. P. Bogdanov, and on obtaining his degree was appointed an assistant and later a lecturer at the Zoological Museum of the University. In 1889, Nassonov joined the University of Warsaw and a year later was appointed to the chair of zoology. In 1909 the Academy of Sciences elected him to membership and he was called to the post of the director of the Academy's Zoological Museum at St. Petersburg. A strenuous period of reorganizing the Museum occupied his time until 1921, when he became director of the Special Zoological Laboratory of the Academy which had been founded by the famous A. O. Kovalevsky. By 1925 this Laboratory, which at first occupied three rooms and had a staff of three men of science, had developed into a large Laboratory of Experimental Zoology and Animal Morphology. It was only in 1935, when eighty years of age, that N. V. Nassonov was persuaded by his medical advisers to retire from active administrative work, but even then he continued researches on regeneration until his death.

The published works of N. V. Nassonov are more than a hundred and seventy in number and deal with a variety of subjects. His earlier morphological work was mainly done on insects and other Arthropoda (ants, Strepsiptera), but later he produced excellent papers on sponges (Clionidx), on the development of the ostrich, on the anatomy and systematics of Turbellaria, a monograph of the wild sheep of the old World, to mention but some of the problems investigated by him with painstaking accuracy and discussed with a broad evolutionary outlook. During the latest period of his work at the Zoological Laboratory, N. V. Nassonov concentrated his attention on regeneration problems, and published a series of outstanding contributions dealing with physiological factors of regeneration, with the morphogenetic function of cartilage, etc.

N. V. Nassonov was well known beyond the borders of his own country, since at various times he visited and worked at the biological stations at Trieste, Marseilles, in the museums in London (1913) and Berlin, and carried out expeditions to Egypt, Sinai and Japan.
N. V. Nassonov's death means the loss of one of the oldest generation of Russian men of science who in the second half of the last century laid the foundation for the development of biological sciences in that country, and whose work served to create for Russian biology an honoured place in the front rank of world science.

B. P. Uvarov.

\section{Prof. H. A. Cummins, C.M.G.}

WE regret to announce the death of Prof. Henry Alfred Cummins, emeritus professor of botany in the University College, Cork. $\mathrm{H}_{\Theta}$ was a member of a family prominent in Cork medical and university life. An elder brother was professor of medicine in the same College.

Cummins was born in 1864. Having taken the M.D. degree in the Royal (now National) University of Ireland, he joined the Royal Army Medical Corps, and was immediately plunged into a series of campaigns. He served in the Sikkim Expedition (1888), Ashanti (1895-96) and in the South African War (1899-1901), during which he was mentioned in dispatches. On the outbreak of the Great War he was recalled for service with the R.A.M.C., and was again mentioned in dispatches. During his military career, he cultivated a keen taste for botany, and managed to collect specimens wherever he might be, even going so far as to shoot epiphytes, otherwise inaccessible, from high forest trees.

In 1909, shortly after his retirement as Major, Cummins was appointed professor of botany in University College, Cork, a constituent college of the National University of Ireland. He held this position until 1931.

Cummins had a personality of considerable charm. $\mathrm{He}$ followed his original interests in spermaphytes with histology and cytology. Just before his retirement, he carried out experiments on the reclamation of estuarine shores near Cork by means of the rice grass, Spartina Townsendii. These appear to have been the first attempts at such reclamation in Ireland.

J. C. Sperrin-Johnson.

WE regret to announce the following deaths :

Prof. F. J. Cheshire, C.B.E., formerly director of the Optical Engineering Department, Imperial College of Science, London, on March 24, aged seventy-eight years.

Prof. Vasili Y. Danilevsky, of Kharkov, known for his work in physiology and endocrinology, on February 25, aged eighty-seven years.

Mr. L. J. Newman, Government entomologist of Western Australia, on December 8, aged sixty years.

Baron Joji Sakurai, honorary professor of chemistry in the Imperial University of Tokyo, president of the Imperial Academy and the National Research Council of Japan, on January 28, aged eighty years.

Prof. John H. Schaffner, professor of botany in the Ohio State University, an authority on the taxonomy and phylogeny of the Ohio and Kansas flora, on January 27, aged fifty-five years. 